\title{
Between Principles and Practice: Grotius' Commitment to Religious Peace in a Contemporary Context*
}

\author{
Bas de Gaay Fortman \\ Honorary Chair in Political Economy of Human Rights \\ Faculty of Humanities, Utrecht University \\ Email: B.deGaayFortman@uu.nl
}

\begin{abstract}
This article discusses Hugo Grotius's 'pamphlet' Ordinum pietas in the political and religious setting of 1613 , attempting to draw some lessons from a contemporary perspective. At a time of religious struggle and strife De Groot felt himself committed to 'religious peace', implying freedom of conscience as a public-political principle coupled with toleration of religious diversity in practice. It is in the context of religious conflict at a time of transition that his allegiance to an established confession and his rejection of sectarian sectarian concepts of theocracy, may be understood. A connection is made to both modern requirements of 'religious peace' and universal human rights as a 'global faith'.
\end{abstract}

\section{Keywords}

Grotius; Ordinum pietas; Lubbertus; religious conflict; church and state; established religion; theocracy; Huguenots; human rights

In the Netherlands the year 2013 gave rise to four centenary celebrations:

1. 1613 as the year in which Hugo Grotius wrote his polemical pamphlet Ordinum Hollandiae ac Westfrisiae Pietas;

2. 1713 as the year in which the Treaty of Utrecht was concluded, which established a certain degree of geographical peace based upon a 'balance of power' that had been the outcome of a time of almost continuous wars;

3. 1813 as the year in which The Netherlands became a monarchy with succession by direct descendants of Prince William VI of Orange Nassau, who had been crowned King William I; and finally

* This article is based on a public lecture given at the Peace Palace on June 13, 2013, on the invitation of the Grotiana Foundation. 
4. 1913 as the year in which the Peace Palace was opened, founded to host international institutions for judicial dispute resolution. It was in the Library of this illustrious edifice with its world famous Grotius collection that the fourth centenary of Ordinum Pietas was celebrated with an international symposium.

This article then, focuses on the year 1613 and hence, evidently, on Hugo de Groot and his polemical pamphlet. At a time at which religious peace continues to be a major challenge, De Groot's approach to religious strife appears to be still enlightening.

With Grotius' pamphlet - literally entitled The piety of the States of Holland and Westfriesland, vindicated against the very base calumnies of many, but especially against the recent letter of Sibrandus Lubbertus - we find ourselves in the Netherlands, four hundred years ago. It was a period of transition, resulting in both 'the division of Christendom into competing confessions' and public-political consolidation of 'units resembling modern nation-states', as University College London Chair in Dutch History Ben Kaplan put it aptly in his profound study Divided by Faith. ${ }^{1}$ Objections to doctrinal extravagancies and moral abuses by the hierarchy had resulted in religious division. Indeed, precisely at a time of modern state-building, the reformation terminated the evident identification between Roman Catholicism and the Sovereign. The Inquisition - supported by the Spanish Authority - had provoked public fury, as expressed in acts of iconoclasm in roman-catholic church buildings.

\section{Grotius' concern with religious conflict}

It was in this religiously and politically turbulent period that Grotius developed an existential concern with religious polarisation. To understand this, one has to take note of the human catastrophes in which religious struggle and strife had already resulted. In a broad perspective of his whole life and work we may well assume that for De Groot peace and the integrity of the public-political community came first. ${ }^{2}$ Notably, the Reformation had not

1 Benjamin J. Kaplan, Divided by Faith. Religious Conflict and the Practice of Toleration in Early Modern Europe (Cambridge, MA/London: The Belknap Press of Harvard University, 2007), p. 101.

2 See Henk Nellen's impressive biography Hugo de Groot. Een leven in strijd om de vrede 1583-1645 (Amsterdam: Uitgeverij Balans, 2007). 
just freed people from the yoke of an intolerant established church coupled with oppression of the freedom of individual conscience but it had also led to human catastrophes of interstate and intrastate collective violence. Above all, it were the French wars of religion that had unequivocally demonstrated the disastrous effects of religious division and intolerance on civil strife resulting in horrendous bloodshed.

Right at the end of this sixteenth century, from March to May 1598, young Hugo - widely admired as a prodigy - had visited France with a delegation of the States of Holland. Undoubtedly he had been made aware of the Edict of Nantes, issued by King Henry IV on 13 April 1598, i.e. during his stay. This pacifying decree sought an end to those wars of intolerance by accepting religious diversity in the setting of civil unity. Thus, the Huguenots had to accept the French Kingdom as their Nation-State and its King as their Sovereign. However, within that polity rights and freedoms to practice their protestant religion would be rather strong south of the Loire, particularly in the crescent of communities reaching from La Rochelle through the southern provinces of Guyenne, Languedoc, and Dauphiné to Geneva, but very weak elsewhere; a sort of religious cleansing in other words. Fifteen years later, when De Groot set himself to his vindication of the piety of the States of Holland against 'scandalous' attacks from a Calvinist theocratic angle, Henry IV had already been assassinated, while the fiasco of his concept for religious peace had become indisputable. In the Republic, too, division by faith had taken its toll in its effects on civil strife and collective violence.

It is in this context that De Groot's anxieties must be understood. Indeed, religious toleration had been consistently pursued by Prince William of Orange and other sixteenth century personalities of great repute. To the Stadholder - in Holland 'High Sovereign' - this implied individual freedom of conscience coupled with 'biconfessionalism'. ${ }^{3}$ An earlier attempt at such a settlement, albeit with a pronounced inclination towards RomanCatholicism, had been the Pacification of Ghent of 1576 , principally meant to unite the seventeen regions of the Netherlands in their revolt against Spanish rule. This treaty recognized the right of the respective States provincial authorities - to publicly administer religion within their own territory; yet, this was tied to an appeal to toleration in respect of the major religion that had been disestablished. Individual freedom of conscience

${ }^{3}$ Cf. Benjamin J. Kaplan, 'In equality and enjoying the same favour: Biconfessionalism in the Low Countries', in A Companion to multiconfessionalism in the early modern world, ed. by T.M. Safley (Leiden: Brill, 2011), pp. 99-126. 
was recognized - stipulating an end to the Inquisition - but not in definite terminology. Three years later the 'Union of Utrecht' followed with a stronger text on individual freedom of conscience, stipulating that 'each person shall remain free, especially in his religion, and that no one shall be persecuted or investigated because of their religion. ${ }^{4}$ The latter phrase had been added at the Prince of Orange's request. Remarkably, in respect of public office this prescription reappears at the only place in the American constitution (1789) that mentions religion: 'no religious test shall ever be required as a qualification to any office or public trust under the United States' (final clause of Art. VI). Notably, the First Amendment to that document (1791) goes quite a bit further, stipulating that 'Congress shall make no law respecting an establishment of religion, or prohibiting the free exercise thereof; or abridging the freedom of speech, or of the press; or the right of the people peaceably to assemble, and to petition the Government for a redress of grievances'. Substantially, this implies freedom of religion in the full sense of Article 18 of the Universal Declaration of Human Rights, adopted more than one and a half century later (1948), which reads:

Everyone has the right to freedom of thought, conscience and religion; this right includes freedom to change his religion or belief, and freedom, either alone or in community with others and in public or private, to manifest his religion or belief in teaching, practice, worship and observance.

While what is declared here is regarded as 'full religious toleration', Grotius' engagement has been termed 'limited religious toleration'. ${ }^{5}$ Although miles away from common political culture those days, the full version was not without prestigious support (by Coornhert for one). Grotius, however, approached the whole issue from a political rather than a philosophical/theological perspective, putting stability and peace on

4 An English translation of the text of the Union of Utrecht is in E.H. Kossman and A.F. Mellink, eds., Texts concerning the Revolt of the Netherlands (Cambridge: Cambridge University Press, 1974), pp. 165-73. See also A. Th. Van Deursen, 'Between Unity and independence: the application of the Union as a fundamental law', The Low Countries History Yearbook, 14 (1981), 50-65, and Juliaan J. Woltjer, 'De wisselende gestalten van de Unie', in De Unie van Utrecht. Wording en werking van een verbond en een verbondsacte, ed. by S. Groeneveld and H.L .Ph. Leeuwenberg (The Hague: SDU, 1979), pp. 88-100.

${ }^{5}$ Freya Sierhuis, 'Controversy and Reconciliation : Grotius, Vondel and the Debate on Religious Peace in the Dutch Republic', in Forgetting Faith? Negotiating Confessional Conflict in Early Modern Europe, ed. by I. Karremann, C. Zwierlein and I. M. Groote (Berlin: De Gruyter, 2012), pp. $141 \mathrm{ff}$. 
top of his public-political agenda. Religious peace, he felt, requires religious unity in a generally accommodating perspective. Yet, while personally he might well have preferred bi-confessionalism - Calvinism with a high degree of tolerance towards Roman-catholic worship or even the other way round - in his days such ideas had already become ancient history. Hence, the political pillars of religious peace had to be limited to freedom of conscience and toleration of non-Calvinist worship through semi-clandestine churches disguised as ordinary houses, barns or warehouses. ${ }^{6}$

Noteworthy in this connection is De Groot's inimical attitude towards certain sectarian congregations like the Anabaptists, which had included the 'Münsterites' who occupied and held the German city of Münster in 1535-6. Given his political focus we may well assume that for Grotius it was not the theological views of sectarians which were decisive here but efforts to create alternative societies. This is remarkably topical today. What drives a growing fear of threats to intra-state peace is not primarily different beliefs and lifestyles of migrated collectivities but distinct ways of relating to the public interest. Indeed, it is not so much individual beliefs which are considered to be problematic but collective tendencies to create parallel societies. Thus, while economic fears of collective migration are likely to be misplaced, tendencies to create socio-political institutions parallel to those based on existing social contracts, merit some serious concern. ${ }^{7}$ Perhaps one should add here that in our time the peril of parallel-society-building symbolized by the slogan 'your law and order is not mine', is not confined to groups based on a common understanding of faith. Just think of the American 'Tea Party' here. But in Grotius' life and times religion was, indeed, the crucial factor.

It is against this background of limited religious freedom at a time in which diverse threats to religious peace and public-political integrity manifested themselves that Ordinum Pietas is to be read and understood. ${ }^{8}$ Doing so in a contemporary perspective, let us now trace its three parts.

${ }^{6}$ See Benjamin J. Kaplan, 'Fictions of Privacy: House Chapels and the Spatial Accommodation of Religious Dissent in Early Modern Europe', American Historical Review 107 (2002), 1031-1064.

7 See, for example, Paul Collier, Exodus: Immigration and Multiculturalism in the $27^{\text {st }}$ Century (London: Allen Lane, 2013).

8 The text is in Hugo Grotius, Ordinum Hollandiae AC Westfrisiae Pietas: English translation with introduction and commentary of this early work by Hugo Grotius on church politics by Edwin Rabbie, (Leiden: Brill, 1995). 


\section{Ordinum Pietas}

Part I on the appointment of Conradus Vorstius to a Divinity Chair in Leiden - to which Sybrandus Lubbertus, Chair in Divinity at Franeker University, had objected with comments on that colleague's alleged 'ninety errors' - confronts us with a rather ill-disposed environment among university professors in general and theologians in particular. It assumes the features of a Shakespearean drama in which intriguing characters appear. The major parts are played by Grotius and his chosen adversary Lubbertus with the two antagonist theologians Arminius and Gomarus as background personalities, while minor roles are performed by figures with names such as Socinus, Emmius, Hommius, Piscator, Bellarminus, Gretzerus, Thysius, Casaubonus, Sandius, Paraeus and Bertius. In the course of events the latter is revealed as the author of an anonymous pamphlet on the doctrine of justification, to which Lubbertus responds with a Libellum contra Anonymum. Indeed, the setting is inimical and utterly suspicious. Secret meetings are held. By sneaky means copies of Grotius' manuscript are already delivered to the addressee (England's King James I) before the actual letter has been posted. Continually, conversations take place in which participants insist on their anonymity. To us today, it is an amusing ambiance at which one might well sneer, if it were not for current settings in modern academia in which personal alliances, scheming, manipulation and recurrent abuse of established principles of due process such as 'Audi et alteram partem' and 'Nemo iudex in sua propria causa' also abound. Notably, in a comparative perspective of three realms of communal decision-making today, public politics in the institutional setting of a democracy with press freedom might well be the least annoying because all manipulation is likely to come out into the open. In academia closed corridors tend to exert an ominous influence. In church politics it is the veil of holiness which is particularly disturbing, with 'Vatileaks' - a scandal that has weighed heavily on emeritus pope Benedict XVI - as present-day testimony. At the time of Ordinum pietas these three domains - politics, academia and religion - were mixed like a cocktail, while there existed neither political democracy nor a free press.

Part II, then, is on piety proper, a crucial issue in Grotius' days. Actually, Festus Hommius had advised his friend Lubbertus to call his response (his Anti-Grotium) 'Impietas Hugonis Grotii in defendenda pietate Ordinum Hollandiae et Westphrisiae'. But while Hommius wanted his preceptor to attack what he considered to be 'impious lies and calumnies' - reciprocal polemics in other words - for Grotius the term piety 
had referred to the solidity of the reformed faith as validated by the States of Holland.

Particularly problematic from a religious peace-making perspective - as typically taken by De Groot - was, indeed, the widely shared conviction 'extra Ecclesiam nulla salus' (outside the church there is no salvation). Although it originated from a Roman Catholic source, this exclusivist interpretation of doctrinal truth became a common obsession among all religions which had secured access to political power or were attempting to do so. In England, for example, the Puritans wanted to chase the whole hierarchy out of the established Church, while the bishops in their turn wanted all Puritans out. ${ }^{9}$ In its effects on inter and intra-state peacekeeping, such fanaticism became particularly perilous when combined with the theological view that transcendental salvation is of ultimate significance. Thus, Calvin's successor Theodore Beza, for one, denounced toleration as a most diabolical doctrine 'because it simply meant that everyone should be left to go to hell in his own way.'10

Another feature of the institutional environment four hundred years ago is the contra-atmosphere in which people apparently developed their thoughts. Indeed, not only was the reformation followed by a Roman-Catholic counter-reformation, protestant confessionalism itself was accompanied by further divisions, today still typified by the aphorism: 'One Dutchman a principle, two Dutchmen a church, three Dutchmen a schism'. Notably, Grotius' religious environment was marked by the split between remonstrants and counter-remonstrants but beware: the remonstrants based themselves upon a petition to the States in which they had formulated five counter arguments against certain elements in established Calvinist confessionalism.

In those days such a religious setting inevitably translated itself into political divisions among factions. So effectually politics became anti-politics. Lamentably, today the atmosphere is scarcely less anti than it used to be four hundred years ago, while the way in which the contestants expressed themselves those days tended to be considerably more respectful - at least formally. Confining ourselves to the contemporary Dutch political scene, it is the Party for Freedom (PVV) that has developed itself into a complete caricature of the politics of against: anti-Europe, anti-Islam, anti-Muslim

9 Cf. Kaplan, Divided by Faith, pp. 136-137.

10 Cited by Ronald David Bedford, The Defence of Truth: Herbert of Cherbury and the Seventeenth Century (Manchester: Manchester University Press, 1979), p. 211. See also Kaplan, op. cit., p. 143. 
immigration, anti-State, anti-'elite' and so on. While probably not capable of attracting more than one fifth of the popular vote, its impact on Dutch political culture appears to be disproportional. Just as in the transitional period of the twelve years' truce during the war of independence with Spain (16og-1621), politics in our current time of transition with their liking for vicious polemics and polarization tends to outstrip a common quest for viable alternatives. Strikingly, it is American democracy that manifests a particularly caricatured testimony to this tendency.

At this point I must admit that my first acquaintance with Ordinum Pietas was not through Grotius but via his chosen adversary Lubbertus. In 1964 Professor Cees van der Woude of Kampen Theological College invited me to his $\mathrm{PhD}$ ceremony, which - in common with the subject of his thesis Sybrandus Lubbertus - took place after his inaugural address on the occasion of accepting his professorial Chair had already been delivered. ${ }^{11}$ In regard to that public lecture Edwin Rabbie provides the following reference: 'On the polemics surrounding Ordinum Pietas see especially C. van der Woude, Hugo Grotius en zijn "Pietas Ordinum Hollandiae ac Westfrisiae vindicata" (Kampen, 1961), which is, however, very prejudiced against Grotius and the Remonstrants in general.' Yet, there is good reason to pay tribute to this Church historian whose doctoral dissertation Sibrandus Lubbertus may well be seen as an impressive testimony to outstanding scholarship. He depicts a typically 'Calvinist' personality preoccupied with doctrinal orthodoxy. ${ }^{12}$ But Lubbertus is also sketched as a gentle and honest personality with a deep love for les beaux-arts. Notably, the two opponents had quite a bit in common, including some friends of great repute, such as Casaubonus and Ubbo Emmius. The latter, who had earlier regretted that Lubbertus' comments on Vorstius' assumed ninety errors had ever been published, privately expressed his doubts on De Groot's polemics with Lubbertus, too. Indeed, the question remains whether young Grotius had made the right decision to pick Lubbertus as the object of those delightful polemics by which he chose to defend the States of Holland. In retrospect Grotius himself too, wondered if he had not gone too far there, an obvious testimony to his capacity of self-reflection. In struggles between principles and practice it is not always easy to find a balance between clarity of commitment and prudent action.

${ }^{11}$ C. van der Woude, Sibrandus Lubbertus. Zijn leven en werken, in het bijzonder naar zijn correspondentie (Kampen: Kok, 1964).

12 Calvin was not a Calvinist, by the way, just as, in the title of Desmond Tutu's latest book, God is not a Christian. 
But at this centenary commemoration our principal drive is not so much to understand seventeenth century personalities but to learn lessons from Ordinum Pietas. Was it really necessary to engage in theological debate, too? The answer is a simple 'yes', because theological issues played a crucial part in their effects on public-political stability. The attack on Vorstius' socalled Socinianism (Unitarian theology) had been aimed at the States of Holland. Political stability naturally required religious peace and toleration, which could not possibly be achieved if the States themselves were seen as heterodox. The only way, then, to assure their orthodoxy was to engage in theological debate, and that had to be done from an immanent orthodox perspective. Hence, Unitarian interpretations of Scripture had to be rejected and Arminian views on predestination and justification had to be elucidated as falling within the limits of orthodox interpretation.

A note on the meaning of orthodoxy may well be apposite here. Literally, it means 'the right praise'. $\Delta \circ \xi \alpha \tau \omega l \theta \varepsilon \omega l$ - hymns to praise God - that is how liturgy set off, and quite naturally the right hymns came to be seen as the right doctrine. In the setting of Church-State relations, there would seem to be no problem with orthodoxy as long as the gates of interpretation remain open, to draw on an expression used in Islamic hermeneutic debate. Fundamentalism in the sense of absolutist and exclusivist doctrinal interpretation is a different matter. Putting doctrine above interpretation implies sinful human domination over Scripture, J.H. Gunning once wrote to Abraham Kuyper. ${ }^{13}$ Such a position usually involves exclusivism in the sense of 'my absolute truth excluding yours', which may well culminate in exceptionalism, entailing ideological licence to take exception to a publicpolitical order that is not based on what is regarded as the right doctrine. Naturally, from a public-political perspective aimed at law and order religious ideology easily becomes a serious threat. ${ }^{14}$ In a contemporary context Jihadism comes to mind here. Security policies to prevent terrorist action based on such an ideology are mandatory of course. Simultaneously, false theological roots of exceptionalist views require disclosure. Not without reason then, Islamic scholars concerned with human rights realisation with colleagues at Mofid University in Iran's holy city of Qom in the

13 J.H. Gunning in a letter to A. Kuyper, dated 18th Jan. 1879., See J.H. Gunning JH Zn, Prof. Dr. J.H. Gunning. Leven en werken, 3 vols (Rotterdam: J.M. Bredée, [1922-25]), III, pp. 970-973.

${ }^{14}$ A thorough analysis of 'coercive religion' in a contemporary context is provided by Emanuel de Kadt, Assertive Religion. Religious Intolerance in a multicultural world (New Brunswick/London: Transaction Publishers, 2013). 
forefront - show a strong commitment towards exposing the heresies in such views..$^{15}$ Notably, while based on a non-fundamentalist (contextual) hermeneutic position, in order to be persuasive such efforts do require an orthodox perspective. Not without reason, then, in his Ordinum Pietas Grotius attempts to manifest himself as an orthodox theologian, too.

Finally at this point, at the end of his elaborate study Van der Woude concludes that Lubbertus did not bring theology forward. Perhaps the same may be said of De Groot's contributions to the theological debate in his days. At any rate, his attempt to qualify Church-State relations from the perspective of a unifying patristic theology coupled with the presumption of an Erasmian 'original' Dutch reformation based on toleration did not put an end to religious struggle and strife in his life and times.

\section{Constitutional establishment of religious institutions}

This brings us to Part III of Ordinum Pietas, which centres on Church-State relations proper. Grotius was convinced the struggle for both good government and a tolerant variety of religious unity required an established Church. His model was the Church of England as established by Elizabeth I. It was meant to unite all citizens in one religious setting in which differences in interpretations would not be exploited for religious, let alone civil, division. For the Netherlands, however, that idea did not work out and today it is as far from Dutch reality as ever. Yet, in our attempt to learn lessons from Grotius' views it merits some attention.

De Groot's idea that an established religious institution as part of the public-political community's social contract were to be conducive to religious peace was not far-fetched. Certainly, at the turn of the first millennium it had worked well in Iceland, a settler society with escalating tensions between at one side the offspring of Vikings from Scandinavia with their pagan gods and at the other side the descendants of Christian Celts from Ireland together with those who had just been converted by newly arrived missionaries from Norway. That story of religious peace-making is both moving and instructive. Once a year Icelanders from all corners of their

15 See Sadegh Haghihat, 'In the Name of Allah: Jihad from a Shi'a Hermeneutic Perspective', in, Hermeneutics, Scriptural Politics and Human Rights. Between Text and Context, ed. by Bas de Gaay Fortman, Kurt Martens and M.A. Mohamed Salih (New York/ London: Palgrave-Macmillan, 2009), pp. 205-219. Also in this volume: Ali Mirmoosavi, 'The Qur'an and Religious Freedom: The Issue of Apostasy', pp. $125 \mathrm{ff}$. 
fierce land came together on the AlPing - an open plain which served as their Parliament - to jointly decide on matters of national interest. Legislation was usually proclaimed by a law-speaker, a man of common esteem and trust. In this case there were two candidates, one Christian and one Pagan. Agreement was reached to entrust the tough task to the Viking nominee Porgeir whose name means spear of Por, the god of thunder on whom people used to call for sea voyages and in difficult situations. ${ }^{16}$ porgeir accepted only after a general assurance that his decision would be final. After two days of silent reflection in his tent he requested people to proceed to the Law Rock where he told them, in the words of Ari, 'that their new society would be in a

sorry plight if men were not to have one law, all of them, in this land; and he put this to men in many ways, how they must never let such a state of affairs come about, maintaining that strife would be the result, so it could be taken as certain that such contention would arise among men that land would be laid waste by reason of it. ${ }^{17}$

Urging the Albing not to let those prevail who are most anxious to be at each other's throats, but reach such compromise in these matters that each will win part of his case, and let all have one law and one faith, Porgeir declared to be law that all Icelanders were Christians and were to be baptised but if pagans still wanted to dedicate infants at the riversides, that could be done. Even sacrifices to the pagan gods would be allowed, but only in secret. ${ }^{18}$

What a lovely compromise between the need for public order and toleration based on people's freedom of conscience! The magic toleration to which Iceland's ecclesiastical setting from then onwards conformed, is magisterially sketched in Nobel prize winner Halldor Laxness's novel Christendom at the Glacier. ${ }^{19}$

Yet, constitutional establishment of a religion is not a synonym for theocracy, meaning God's rule. As God's will cannot be indisputably determined, it is religious leaders who actually decide on laws, policies and executive orders. The Islamic republic of Iran illustrates what this entails: power to clerics without accountability. In De Groot's days Church leaders indeed believed the confederated states of the United Republic should be

\footnotetext{
16 See Richard F. Tomasson, Iceland. The First New Society (University of Minnesota Press, 1980), pp. 178-179.

17 Id. at 179 .

18 Ibid.

19 Kristnihald undir Jökli (Reykjavik: Helgafell, 1968).
} 
under their auspices through censura morum of all public officials, too. Against this theocratic model Grotius argued for recognition of the full sovereignty of the state, which should no longer be challenged on the basis of distinct theological convictions. Quoting the Apostle Paul in his $1^{\text {st }}$ letter to the Corinthians - 'the spirits of the prophets are subject to the prophets' (14: 29-32) - Kirchenführer like Lubbertus, however, rejected religious submission to secular leadership. While neither view gained full constitutional adoption, the role of the Dutch Reformed Church in state affairs remained quite dominant. By its combination of Cuius regio eius religio with recognition of religious minority rights it was the peace of Westphalia of 1648 that laid a constitutional foundation for pacifying political systems from within.

Grotius, then, had witnessed the pacifying impact of an established religion, not only in England but also in the Scandinavian countries. But a problem with Calvinism as interpreted by the Church leaders was the tendency to continuously split up in evermore 'sects' and 'new parties' on the basis of theological division on 'not very serious points'. ${ }^{20}$ Naturally, Grotius was aware of the successful establishment of Lutheranism with its Augsburg confession as a Book of Concord in the Scandinavian countries. At the time of the reformation in Iceland, too, Lutheranism had become the established religion, simply through a top-down decision by Danish rulers. Yet, Calvinism has nowhere achieved such a widely unifying and pacifying position. Should the cause of that disappointment be traced to the spirit of the Dutch Confession and the Heidelberg Catechism together with the 'counter-remonstrant' Canons of Dordt, or to a divisive religious culture in the Low Countries, or, perhaps, to both?

\section{Freedom of worship}

Constitutional establishment of religion not automatically coincides with toleration, as history has rather awkwardly shown. On the contrary, it has often served to legally justify terrible oppression and persecution, with the Inquisition as major testimony to religious abuse. Nor should Disestablishment be seen as a secularist threat to religious freedom. Taking the United States as an example here, establishment of whatever religion or faith has been explicitly outlawed in its first amendment, not only in line with its core principle of people's sovereignty but also in order to guarantee

20 Hugo Grotius, op. cit. (note 8), p. 171. 
fundamental freedoms including those of worship and speech. Yet, while in state affairs theology is seen as a threat, religion definitely is not. Remarkably, there are few countries in which there is so much religion in the public realm, not to mention explicit and implicit use and abuse of religion for party-political purposes. In the Netherlands, however, there is a growing aversion to any kind of manifestation of religion in the civic sphere. In both instances Grotius' views on a multi-religious society are still topical.

As already stated, Ordinum pietas was written at a time when full freedom of religion was far removed from common political thinking and practice. Yet, while still a professed Roman-Catholic, Stadholder William of Orange had actively acclaimed freedom of conscience in his famous speech on New Year's eve 1564: 'Je suis décidé à rester catholique, mais je ne puis pas approuver que les princes veuillent commander aux consciences humaines et supprimer la liberté de foi et de religion.' As noted, this view culminated in Article 13 of the Union of Utrecht of 1579.

Strikingly, while this component of religious liberty had been incorporated in a treaty between Brabant and Flanders as far back as 1339, toleration limited to just individual beliefs already appears to encounter ideological opposition. Thus, in Massachusetts under theocratic (puritan) rule members of the Society of Friends (Quakers) were condemned to death for their religious beliefs and executed by public hanging in 1659 , 1660 and 1661 ('the Boston martyrs'). Behind such acts of atrocity was religious ideology. What is problematic here is not so much religion but ideology, implying a doctrinal basis for us/them divides. Indeed, as late as the 1950s McCarthyism served as an anti-communist ideological drive to persecute and even prosecute Americans for their thoughts and beliefs.

Yet, where ideology drives intolerance in principle, enlightened views on religious diversity such as those propounded by Grotius may well have contributed to practical toleration. Besides acceptance of the freedom to think and believe differently, this concerns collective freedom of worship in particular. Indeed, while reluctantly the States of Holland had outlawed Catholic worship, too, through semi-clandestine churches (schuylkerken) practice was not rigid.

\section{Political economy of religious freedom}

Actually, constitutional issues regarding religious freedom are just accessory to three major issues in respect of economic consequences of religious division, conflict and strife. This crucial matter may be illustrated by 
reference to the negotiations leading to the pacification of the Nantes Edict. Rather than insisting on religious cleansing, the Huguenots had formulated three major demands. ${ }^{21}$

1. guaranteed freedom of worship for the Protestant (Reformed) religion in the whole Kingdom of France without any restriction as to time and place;

2. guaranteed equal access to office, whatsoever; and

3. guaranteed personal security for all citizens, including those of the reformed faith. ${ }^{22}$

The failure to grant these guarantees had forced the Huguenots to further organise as a strong religious minority, dependent on auto-protection. This resulted in collective political and military organisation. Where they were in control they adopted policies of discrimination against the Catholics in their turn. Under Louis XIV they were crushed; the Edict of Nantes, although registered by the legislatures in 1598 as fundamental and irrevocable law, was revoked in 1685 . Protestantism was declared illegal; as a result, the following century until the French Revolution was a time of unrestrained anti-Protestant tyranny, persecution and oppression. Hundreds of thousands of Huguenots fled hearth and home.

It is instructive here to pay heed to the second Huguenot request, which amounts to equal economic opportunities. The lack of perspective resulting from politico-economic exclusion has proven to be a major factor contributing to intra-state violence-both then and now. The following observation from Adam Smith's Wealth of Nations, published in 1776, may still serve as a starting point here:

[C]ommerce and manufacturers gradually introduced order and good government, and with them the liberty and security of individuals, among the inhabitants of the country, who had before lived almost in a continual state of war with their neighbours, and of servile dependency upon their superiors. ${ }^{23}$

\footnotetext{
21 See Pierre L. van Enk, Frankrijk en de Hugenoten. Drie eeuwen onderdrukking en verzet (Zoetermeer: Boekencentrum, 2004), p. 334.

22 A similar but more modern reiteration of these basic guarantees for 'minority protection' was contained within the (admittedly weak) International Protection of Minorities System that functioned under the League of Nations at the time before World War II. See Y. Dinstein, 'Collective Human Rights of Peoples and Minorities', International and Comparative Law Quarterly 25 (1976), 102-120.

${ }^{23}$ Adam Smith, An Inquiry Into the Nature and Causes of the Wealth of Nations (London: Routledge $1900 ; 1^{\text {st }}$ edn 1776$)$, p. 313 .
} 
As a structural basis for peace and political stability, this presumes nondiscrimination in trade and employment, too. Equally, the third Huguenot demand obtains: protection of everyone against violence. This may still be seen as the most important function of the State: law and order, aiming at equal protection of all in respect to:

1. their person, implying not only protection against the State in the sense of security of person, but also protection by the State against criminality;

2. their goods, implying solidity of entitlement positions, which is both more and less than the right to own property as such, and

3. their deals, implying the execution of contracts (pacta sunt servanda, a principle Grotius stressed as being fundamental) through an 'exact administration of justice. ${ }^{24}$

Today we are well aware that all this requires a strong state based on an inclusive social contract and commitment to the rule of law. The guarantees the Huguenots sought are, indeed, the basic due any citizen should expect from the state.

\section{Article 1 of the Universal Declaration as global faith}

Finally, while in the last four hundred years our world has witnessed unspeakable acts of barbarism, there has also been invaluable progress in line with Grotius' major mission to ground peace in international justice. It was after the unspeakable cruelties and mass destruction of World War II that the United Nations were founded upon 'a reaffirmed faith', as it was put in the preambles of both the United Nations Charter of 1945 and the Universal Declaration of Human Rights of 1948, 'in fundamental human rights, in the dignity and worth of the human person, in the equal rights of men and women and of nations large and small'. ${ }^{25}$ This global credo culminates in the opening article of the Declaration: 'All human beings are born free and equal in dignity and rights. They are endowed with reason and conscience and should act towards one another in a spirit of brotherhood.'

Notably, however, this article of global faith is not to be regarded as Faith with a capital F, as the Declaration is meant to provide a universally shared reference for the protection of human dignity through inalienable rights

\footnotetext{
24 A term coined by Smith, op. cit., p. 540.

25 United Nations, Charter of the United Nations, 24 October 1945, 1 UNTS XVI.
} 
common to all, irrespective of differences in world views and/or religious beliefs. Hence Article 1, too, needs contextual efforts to connect its global faith in all-inclusive human dignity with specific transcendental belief systems and institutions to which people in their own contexts feel attached. Such linking to people's own life experiences - the socio-economic, political and cultural landscapes in which right-holders live ${ }^{26}$ - is a condition of its legitimacy. ${ }^{27}$ Common acceptability based on institutions, principles, processes and outcomes that are acknowledged as 'right' is, indeed, a major requisite for the implementation of values, norms and rules. In respect of human rights, this entails that its fundamental standards as formulated in crucial texts such as Article 1, are examined and discussed in contextual settings, too, as these are to be linked to people's own (moral) frames of reference on 'right' and 'wrong'. Consequently, global efforts to realise human rights, need to be sustained in positive connections to people's religious convictions and world views.

In other words, passive toleration of religious diversity is one thing, active grounding of inclusive human dignity and fundamental freedoms and basic entitlements for all in both religious and secular beliefs is another crucial condition for global peace. 'Truthfully', Grotius wrote in 1622, 'everything is subject to misinterpretation, including Holy Scripture, but those who love peace interpret all things towards peace. ${ }^{28}$ To this phenomenal scholar and politician, then, peace transcends everything else, including scriptural politics, hermeneutic polemics and economic self-interest; and possibly even the piety of the States of Holland too.

26 The term originates from Jürgen Habermas, who distinguishes between 'system' and 'lifeworld'. While by its international manifestation in documents and institutions the human rights mission presents itself as a system, it is in lifeworlds that human rights have to take roots. See: B. de Gaay Fortman, Political Economy of Human Rights. Rights, Realities and Realization (Routledge, London/New York, 2012), pp. 14 ff.

27 As to the meaning and implications of legitimacy in respect of human rights, see: B. de Gaay Fortman, 'Human Rights as 'Regulae Iuris': An Inquiry into the Dialectics of Legality versus Legitimacy', European Review of Private Law 20 (2012), 409-424.

28 Quoted by Nellen, op. cit. (note 2), p. 609 (this author's translation). 